Jurnal Mandala Pharmacon Indonesia, Vol 4.No.2 Desember 2018

Avaiable online at www.jurnal-pharmaconmw.com/jmpi

$p$-ISSN : 2442-6032

e-ISSN : 2598-9979

\title{
Aktivitas Antibakteri Ekstrak Kulit Buah Kelor (Moringa oleifera) Terhadap Bakteri Staphylococcus aureus
}

Muthmainah Tuldjanah

Program Studi D3 Farmasi, Sekolah Tinggi Ilmu Farmasi Pelita Mas Palu

\begin{tabular}{|c|c|}
\hline BSTRAK & \\
\hline $\begin{array}{l}\text { Telah dilakukan pengujian aktivitas antibakteri } \\
\text { Staphylococcus aureus ekstrak etanol kulit buah } \\
\text { kelor (Moringa oleifera). Penelitian ini bertujuan } \\
\text { untuk mengetahui kandungan metabolit sekunder } \\
\text { pada ekstrak etanol kulit buah kelor (Moringa } \\
\text { oleifera) dan mengetahui aktivitas antibakteri } \\
\text { ekstrak kulit buah kelor (Moringa oleifera) terhadap } \\
\text { bakteri Staphylococcus aureus. Metode yang } \\
\text { digunakan untuk menguji aktivitas antibakteri } \\
\text { adalah metode paper Disk, dimana metode ini } \\
\text { dilakukan dengan menggunakan bakteri } \\
\text { Staphylococcus aureus yang dibiakan dengan } \\
\text { menggunakan lidi kapas yang telah disterilkan. } \\
\text { Kemudian ekstrak kulit buah kelor (Moringa } \\
\text { oleifera) yang diperoleh, diletakkan diatas kertas } \\
\text { cakram yang telah direndam selama } 15 \text { menit } \\
\text { dengan ekstrak kulit buah kelor. Hasil penelitian } \\
\text { menuniukan bahwa ekstrak kulit buah kelor }\end{array}$ & $\begin{array}{l}\text { (Moringa oleifera) memiliki kandungan metabolit } \\
\text { sekunder berupa alkaloid, flavonoid, tanin, } \\
\text { saponin dan polifenol. Aktivitas antibakteri } \\
\text { Stapylococcus aureus pada konsentrasi 5\%, } 10 \% \text {, } \\
\text { 15\%, memilki zona daya hambat yang paling baik } \\
\text { yaitu pada konsentrasi } 15 \% \text { dengan diameter daya } \\
\text { hambat yaitu 15,19 mm pada bakteri Stapylococcus } \\
\text { aureus. } \\
\text { Kata Kunci : Kulit buah kelor (Moringa oleifera,) } \\
\text { antibakteri, Staphylococcus aureus } \\
\text { Penulis Korespondensi : } \\
\text { Muthmainah Tuldjanah } \\
\text { Program Studi D3 Farmasi, Sekolah Tinggi Ilmu } \\
\text { Farmasi Pelita Mas Palu } \\
\text { E-mail : muthmainah.tuldjannah@gmail.com }\end{array}$ \\
\hline
\end{tabular}

\section{PENDAHULUAN}

Bakteri merupakan organisme yang relatif sedehana karena materi genetiknya tidak diselimuti oleh selaput membran inti. Bakteri juga memiliki bentuk dan ukuran yang beragam. Umumnya sel bakteri memiliki diameter 0,2-2 $\mu \mathrm{m}$ dan panjang 2-8 $\mu \mathrm{m}$ (Radji, 2019). Aktivitas bakteri Staphylococcus aureus yang dapat menginfeksi kulit dan diatasi dengan obat antibakteri. (Poeloengan dkk 2007)
Obat antibakteri banyak beredar atau di jual di apotik-apotik penggunaan obat antibiotik yang tidak tepat dan berlebihan dapat membahayakan kesehatan, hal ini dapat dilihat dari efek samping penggunaan obat antibakteri. Faktor tersebut membuat beberapa Masyarakat, lebih memilih pengobatan Tradisional yang umum diperoleh dari bahan alami. Salah satunya ialah Tanaman kelor merupakan tanaman perdu dengan ketinggian 5-11 meter dan 
tumbuh subur mulai dari dataran rendah sampai ketinggian $600 \mathrm{~m}$ di atas permukaan laut. Kelor dapat tumbuh pada daerah subtropis dan tropis pada semua jenis tanah dan musim kering dengan toleransi terhadap kekeringan sampai 5-6 bulan. (Maulida, Dewi 2010)

Bagian tanaman yang sering di gunakan oleh masyarakat salah satunya adalah buah kelor Menurut penelitian yang dilakukan oleh Lusi L. R.H dkk pada tahun 2016 bahwa daun kelor memiliki aktivitas sebagai antibakteri pada konsentrasi $(5 \%, 10 \%, 15 \%)$. Masyarakat kota palu pada umumnya sering mengkonsumsi buah kelor sebagai sayur, namun kulit dari buah kelor hanya di jadikan sebagi limbah. Penelitian ini bertujuan untuk mengetahui kandungan metabolit sekunder pada ekstrak etanol kulit buah kelor (Moringa oleifera) dan mengetahui aktivitas antibakteri ekstrak kulit buah kelor (Moringa oleifera) terhadap bakteri Staphylococcus aureus.

\section{METODE PENELITIAN}

Penelitian ini merupakan peneliti eksperimental dengan menggunkan metode Paper Disk untuk melihat efek ekstrak kulit buah kelor (Moringa oleifera) Terhadap pertumbuhan bakteri Staphylococcus aureus.

\section{Alat Dan Bahan}

Alat-alat yang di gunakan antara lain: cawan petri, timbangan analitik, autoklaf, labu erlenmeyer, tabung reaksi, jangka sorong, inkubator, batang pengeduk, busen, swab, membran filter, kertas label, aluminium foil, masker, handscoon, pipet ukur, filer, pinset, dan gelas ukur.

Bahan-bahan yang di gunakan dalam penelitian ini antara lain: bakteri Staphylococcus aureus, ekstrak kulit buah kelor (Moringa oleifera), etanol, 96\% aquades, amoxicillin.

\section{Waktu dan Tempat Penelitian}

Waktu Dan tempat Penelitian dilaksanakan di bulan April - Juni 2018. Pegujian Aktivitas Antibakteri di lakukan di Laboratorium kesehatan Provinsi Sulawesi Tenggah Kota Palu. Pengujian penapisan fitokimia di lakukan di laboratoruim Farmakognosi dan fitokimia Akademi Farmasi Medika Nusantara Palu.

\section{Pembuatan Uji ekstrak}

Pembuatan ekstrak etanol kulit buah kelor (Moringa oleifera) di lakukan dengan cara maserasi menggunakan pelarut etanol 96\%. Serbuk simplisia kulit buah kelor (Moringa oleifera) sebanyak 456 gram dimaserasi dengan menggunakan 
etanol 90\% sebanyak 4 liter. Ekstrak kental kulit buah kelor (Moringa oleifera) yang diperoleh dari hasil ekstraksi adalah 113 gram dengan nilai rendemen 24,78\%.

\section{Penapisan Fitokimia}

a. Uji alkaloid

Ekstrak ditimbag sebanyak $50 \mathrm{ml}$ ditambahkan ke dalam tabung reaksi, lalu ditambahkakan 2 ml Ekstrak kulit buah kelor kemudian ditambahkan $1 \mathrm{~mL}$ asam klorida $2 \mathrm{~N}$ dan $5 \mathrm{~mL}$ aquades. Selanjutnya dipanaskan di atas penangas air selama 2 menit, dan didihkan. Kemudian disaring dan fitranya ditampung. Fitrat digunakan sebagai larutan percobaan selanjutnya: Larutkan percobaan 2 tetes 2 tetes reagen dragendrof, terbentuk endapan jingga atau coklat menandakan bahwa ekstrak mengandung alkaloid.

b. Uji flavonoid

Ekstrak sebanyak 0,3 mg kemudian dimasukkan ke dalam tabung reaksi lalu ditambahkan $2 \mathrm{~mL}$ aquades 90\% . Ekstrak kulit buah kelor ditambahkan serbuk $\mathrm{Mg}$ dan ditambahkan asam klorida pekat. Terbentuknya warna kuning, orange dan merah menandakan bahwa ekstrak mengandung flavonoid. c. Saponin

Ekstrak sebanyak 0,2 mg dimasukkan ke dalam tabung reaksi lalu ditambahkan $5 \mathrm{~mL}$ etanol 90\%. Ekstrak kemudian ditambahkan $10 \mathrm{mg}$ air panas, lalu didinginkan. Selanjutnya dilakukan pengocokan vertikal selama 10 dertik dan didiamkan selama 15 menit. Terbentuknya buih setinggi $1 \mathrm{~cm}$ dan tidak hilangnya buih setelah penambahan 5 tetes asam klorida $2 \mathrm{~N}$ menandakan bahwa ekstrak mengandung saponin.

d. Uji Tanin

Satu $\mathrm{ml}$ ekstrak ditambahkan dengan sedikit larutan gelatin dan lima $\mathrm{ml} \mathrm{NaCl}$ 10\%. Reaksi positif apabila terbentuk endapan kekuningan.

e. Polifenol

FeCl3 1\% ditambahkan dengan ekstrak etanol kulit buah kelor hingga terjadi perubahan warna, lalu warnanya dibandingkan dengan ekstrak murni, maka akan tampak warna lebih hitam jika positif. Derajat disesuaikan dengan perubahan warna yang terjadi.

\section{A. Pengujian Ekstrak Terhadap Bakteri}

\section{Sterilisasi Alat dan Bahan}

Seluruh alat yang dapat kita digunakan dicuci bersih lalu di dikeringkan. Tabung reaksi, gelas ukur 
dan erlenmeyer ditutup rapat-rapat mulutnya dengan kapas. Cawan petri dibungkus dengan kertas alumunium voil. Kemudian semuanya dimasukkan dalam plastik tahan panas dan disterilkan dengan autoklaf pada suhu $121^{\circ} \mathrm{C}$ selama 2 jam. Pinset dan jarum ose disterilkan dengan cara memijarkan pada api busen

Seluruh media (Natrium Agar) disterilkan dengan autoklaf pada suhu $121^{\circ} \mathrm{C}$ selama 15 menit. Pengerjaan aseptis dilakukan di dalam alat Laminar Air Flow yang sebelumnya telah dibersihkan dengan larutan alkohol 70\%, lalu disterilkan dengan lampu UV yang dinyatakan selama kurang lebih 1 jam sebelum digunakan (Pratiwi, 2011)

\section{Pembuatan Medium Natrium Agar}

Timbang NA 2 g lalu masukan ke dalam erlemeyer dilarutkan dengan aquades $100{ }^{\circ} \mathrm{C}$ dipanaskan hingga larut sempurna kedalam (water bat) lalu Erlemeyer ditutup dengan aluminium foil lalu disterilkan menggunakan otoklaf pada suhu $121^{\circ} \mathrm{C}$ selama 15 Menit Setelah itu buka autoklaf keluarkan medianya biarkan hingga mencapai suhu kurang lebih $45^{\circ} \mathrm{C}$ Setelah itu tuang ke dalam petri disk yang suda di sterilkan sebanyak $20^{\circ} \mathrm{C}$ biarkan hingga membeku dan bungkus media siap di gunakan. (Silvikasari, 2011)

\section{B. Pengolahan Dan Analilis Data}

Analisis penelitian dilakukan dengan mengguanakan analisis statistik yaitu One Way ANOVA untuk mengetahui adanya distribusi normal atau tidak. Jika hasil menunjukan distribusi normal maka dilanjutkan dengan uji Duncan'sdan uji post hoc tests LSD (Leas Signifikan Difference),

\section{HASIL DAN PEMBAHASAN}

\section{Hasil Penelitian}

a. Hasil uji Kualitatif

Berdasarkan hasil pengamatan pada uji Kualitatif pada kulit buah kelor (Moringa oleifera) dapat dilihat pada table 1 .

b. Hasil pengukuran diameter zona daya hambat ekstrak kulit buah kelor (Moringa oleifera) terhadap pertumbuhan Staphylococcus aureus secara Horizontal (H), vertikal (V) dan diagonal (D) dapat dilihat pada table 2 . 
Tabel 1. Hasil uji kualitatif ekstrak kulit buah kelor (Moringa oleifera)

\begin{tabular}{|c|c|c|c|c|}
\hline \multirow{2}{*}{ No } & \multirow{2}{*}{$\begin{array}{c}\text { Senyawa } \\
\text { Bioaktif }\end{array}$} & Pereaksi & \multicolumn{2}{|c|}{ Hasil Pengamatan } \\
\cline { 4 - 5 } & Alkaloid & Dragendrof & $\begin{array}{c}\text { Terbentuknya endapan } \\
\text { coklat }\end{array}$ & Keterangan \\
\hline 1. & $\mathrm{HCl}$ pekat & $\begin{array}{c}\text { Terbentuknya warna } \\
\text { kuning }\end{array}$ & + \\
\hline 2. & Flavonoid & Dikocok $+\mathrm{HCl} 2 \mathrm{~N}$ & $\begin{array}{c}\text { Terbentuknya busa } \\
+\end{array}$ & + \\
\hline 3. & Saponin & $\mathrm{NaCl} 10 \%+\mathrm{FeCl}_{3}$ & $\begin{array}{c}\text { Terbentuknya warna } \\
\text { kuning }\end{array}$ & + \\
\hline 4. & Tanin & $\mathrm{FeCl}_{3}$ & $\begin{array}{c}\text { Terbentuknya warna } \\
\text { ekstrak yang lebih hitam }\end{array}$ & + \\
\hline 5. & Polifenol & & \multicolumn{2}{|c|}{} \\
\hline
\end{tabular}

Keterangan :

$(+)=$ simplisia mengandung golongan senyawa yang diuji

$(-)$ = simplisia tidak mengandung golongan senyawa yang diuji

Tabel 2. zona daya hambat ekstrak kulit buah kelor (Moringa oleifera)

\begin{tabular}{|c|c|c|c|c|c|}
\hline P.1 & $5 \%(\mathrm{~mm})$ & $10 \%(\mathrm{~mm})$ & $15 \%(\mathrm{~mm})$ & $\mathrm{K}+(\mathrm{mm})$ & $\overline{\mathrm{K}-(\mathrm{mm})}$ \\
\hline $\mathrm{H}$ & 11,13 & 13,21 & 15,10 & 48,92 & 0 \\
\hline $\mathrm{V}$ & 11,17 & 13,32 & 14,87 & 49,05 & 0 \\
\hline $\mathrm{D}$ & 12,10 & 13,28 & 15,18 & 49,10 & 0 \\
\hline Rerata & 11,46 & 13,27 & 15,05 & 49,02 & 0 \\
\hline \multicolumn{6}{|l|}{$\overline{P .2}$} \\
\hline $\mathrm{H}$ & 9.80 & 13,21 & 15,20 & 48,88 & 0 \\
\hline V & 10,10 & 12,95 & 15,17 & 48,93 & 0 \\
\hline $\mathrm{D}$ & 10,12 & 13,14 & 15,22 & 48,95 & 0 \\
\hline Rerata & 10,00 & 13,1 & 15,19 & 48,92 & 0 \\
\hline \multicolumn{6}{|l|}{ P.3 } \\
\hline $\mathrm{H}$ & 10,19 & 12,89 & 14,97 & 49,80 & 0 \\
\hline V & 11,16 & 13,10 & 15,10 & 50,14 & 0 \\
\hline $\mathrm{D}$ & 11,18 & 13,21 & 15.13 & 50,10 & 0 \\
\hline Rerata & 10,84 & 13,06 & 15.06 & 50,01 & 0 \\
\hline
\end{tabular}

Keterangan :

P1 percobaa pertama

P2 percobaan kedua

P3 percobaan ketiga

\section{PEMBAHASAN}

Penelitian kulit buah kelor (Moringa oleifera) mengenai daya hambat pada bakteri Staphylococcus aureus telah dilakukan.
Pertama-tama yang dilakukan pada penelitian ini ialah pembuatan ekstrak kulit buah kelor (Moringa oleifera), dengan menggunakan metode maserasi dimana simplisia direndam 
selama 3×24 jam dengan menggunakan etanol 96\%. filtrat dari ekstrak kulit buah kelor (Moringa oleifera) diambil dan dipisahkan dari ampasnya, kemudian dirotavapor sehingga meghasilkan, ekstrak kental, ekstrak kental yang dihasilkan. Dari hasil ekstrak kulit buah kelor yang dihasilkan dilakukan beberapa pengujian diantaranya uji fitokimia dan uji daya hambat.

Uji fitokimia ekstrak kulit buah kelor (Moringa oleifera) yang telah di lakukan pada Labolatorium F-MIPA prodi Farmasi Universitas Tadulako data yang diperoleh menunjukan bahwa ekstrak kulit buah kelor (Moringa oleifera) positif mengandung senyawa alkaloid, , steroid, tanin,. Setelah pengujian fitokimia dilakukan, ekstrak kulit buah kelor (Moringa oleifera) dibagi menjadi beberapa konsentrasi yaitu, 5\%,10\%,15\%, masing-masing konsentrasi, kemudian diuji daya hambatnya dengan menggunakan metode paper disk. Selain menggunakan variasi konsentarsi penelitian ini juga menggunakan kontrol positif (Amoxiccilin) dan kontrol positif ( $\mathrm{NaCMC}$ ).

Hasil uji daya hambat menunjukan nilai yang berbeda-beda yaitu pada konsentarsi 5\% sebesar 10,76 mm, konsentarsi $10 \%$ sebesar 13,14 mm konsentasi 15\% 15,1 $\mathrm{mm}$. Hasil yang diperoleh dari masingmasing konsentrasi ekstrak kulit buah kelor (Moringa oleifera) pada konsentasi 5\%,10\%,15\% menunjukkan adanya zona daya hambat yang dikatakan kuat yaitu sebesar (>5- 20) $\mathrm{mm}$, zona daya hambat dikatakan sangat kuat yaitu sebesar (10-20) mm, zona daya hambat kuat sebesar (5-10) mm dan zona daya hambat dalam kategori sedang, sebesar (0-5). Dari data yang didapatkan menunjukan bahwa dari konsentrasi 5\%,10\%, 15\% sudah menghasilkan daya hambat yang kuat tapi tidak sebanding dengan amoxicicilin, karena amoxcicilin lebih tinggi daya hambatnya dibandingkan dengan 5\%,10\%,15\%, variasi konsentrasi ekstrak. Kulit buah kelor kontrol positif menunjukan daya hambat 49,3. Hasil ini sesuai dengan lieratur yang menyatakan bahwa (Hapsari , 2015).

Amoxicicilin merupakan golongan bakterisida (mematikan sel-sel bakteri) (Kaur et al 2011). Amoxicicilin sendiri memiliki mekanisme yang dapat meghambat dinding sel bakteri dengan mengikat satu cincin penicillin-binding protein (seperti, Karboksi peptisida, endopeptidasi, dan transpeptidasi). Pada membran sitoplasma (Castle 2007). Kontrol negatif yang digunakkan pada penelitian ini adalah $\mathrm{Na} \mathrm{CmC}$ dari hasil yang di tunjukan $\mathrm{Na} \mathrm{CmC}$ tidak memiliki zona daya hambat pada paper disk karena hal ini diduga bahwa NaCMC tidak dapat bereaksi pada senyawa organik sehingga tidak terbentuk zona daya hambat (Nithiya $\mathrm{T}$, 2015).

Pengujian statistik uji daya hambat ekstrak kulit buah kelor (Moringa oleifera) 
dilakukan dengan menggunakan metode satu arah (One Way Anova). Bardasarkan uji analisi statistik anova menunjukan hasil yang tidak signifikan antara semua perlakukan. Hal ini ditandai dengan $\mathrm{p}=0,000(\mathrm{p}<0,05)$, menunjukan adanya perbedaan yang signifikan, sehingga dilanjutkan uji post hoc tests LSD (Leas Signifikan Difference), untuk melihat perbedaan yang bermakna antara masing-masing perlakuan. Hasil uji lanjut post hoc test LSD menunjukan, bahwa masing-masing perlakuan memiliki nilai dimana $0,000(p<0,05)$.

Pengujian aktivitas antibakteri pada penelitian ini menunjukan bahwa konsentrasi yang memiliki aktivitas antibakteri yang paling besar daya hambatnya pada konsentrasi 15\%. Hal ini ditunjukan pada hasil daya hambat pada tabel 4.2.

\section{KESIMPULAN DAN SARAN}

\section{Kesimpulan}

1. Ekstrak kulit buah kelor positif mengandung senyawa metabolit sekunder berupa flavonoid, alkaloid, saponin, tanin, dan fenolik.

2. Ekstrak kulit buah kelor memiliki aktivitas daya hambat terhadap bakteri Staphylococcus aureus.

3. Ekstrak kulit buah kelor dengan konsentrasi $5 \%, 10 \%, 15 \%$ menunjukan adanya perbedaan aktivitas antibakteri.

\section{SARAN}

a. Penelitian selanjutnya sebaiknya mengetahui kandungan senyawa spesifik yang berkhasiat sebagai antibakteri pada tanaman kulit buah kelor (Moringa oleifera) dan aktivitas antibakterinya terhadap bakteri lain.

b. Pada peneliti selanjutnya sebaikan perlu di lakukan uji kepekaan terhadap ekstrak kulit buah kelor (Moringa oleifera) .

\section{DAFTAR PUSTAKA}

Castel, S.Sivia., 2007. xPharm: The Comprehensive Pharmacology Reference. Nethderland: Elsevier, 905-909

Faisal, M., Fatimawati., Wewenagkang, D,S. 2015. Uji Kepekaan Bakteri yang Diisolasi dan Diidentifikasi dari Sputum Penderita Bronkhitis di RSUP Prof dr. R. D. Kandou Manado terhadap Antibiotik Golongan Sefalosporin (Sefiksim), Penisilin (Amoksisilin) dan Tetrasiklin (Tetrasiklin). PHARMACON Jurnal Ilmiah Farmasi- UNSRAT Vol. 4 No 3: 88-95.

Hapsari, Maria Endah. 2015. Uji Aktivitas Antibakteri Ekstrak Herbal (phyllanthus niruri) Terhadap Pertumbuhan Bakteri Bacillus cereus Dan Escherichia coli Skripsi. Universitas sanata Dharma.Yogyakarta. Hal:8-3.

Kaur, S.P., Rao, R., Nanda, S., 2011, Amoxicicillin : A Broad Spectrum Antibiotic, International Jurnal Of Pharmaceutical Sciences, 3(3), 33.

Maulida, Dewi. 2010.Ekstrak Antioksidan (Likopen) Dari Buah Tomat Dengan Menggunakan Solven Campuran, N- 
Heksana, Aseton dan Etanol. Skripsi. Semarang: Universitas Diponegoro. Nithiya T, Vijayalakshmi R, Antimicrobial activity of fruit extract of annona squamosa L, WJPPS. 2015; 4(5):125767

Poeloenga, M., Andriani, Susan, M. N., K. Iyep, dan H. Mirzan. 2007. Uji Daya Antibakteri ekstrak etanol kulit batang bungur (Largerstroremia speciosa Pers) terhadap Staphylococcus aureus dan
Escherichia coli secara In vitro. Seminar Nasional Teknologi Peternakan dan Veteriner.edisi 23

Pratiwi , Nursitasari. 2011. Uji Aktivitas Antibakteri dan Mekanisme Penghambat Ekstrak Air Campuran Daun (piper betle L,) dan Kaput Sirih terhadap Beberapa Bakteri Uji. Jurusan Farmasi, Fakultas Kedokteran dan Ilmu Kesehatan, Universitas Islam Negeri Syarif Hidayahtullah. Jakarta hal 23-26 